\title{
Analysis on Relationship between the Agriculture in Maoming with Local Economic Growth
}

\author{
Yan-Li XU, Ya-Xin WANG \\ School of Business \\ Lingnan Normal University \\ Zhanjiang, Guangdong, P. R. China, 524048 \\ xuyanli_2010@126.com
}

\author{
Zhi-Xian TANG \\ School of Economics \& Management \\ Guangdong University of Petrochemical Technology \\ Maoming, Guangdong, P. R. China, 525000
}

\begin{abstract}
This paper is designed to promote the development of local economy in Maoming. In order to explore the relationship between agriculture and the growth of the local economy, the local GDP and the production of city's main agricultural products in 2000-2012 are selected to yield cointegration test. By using econometrics to set up multivariate regression, it is concluded that not only is agricultural growth positively correlated with the local economy in Maoming city, but a long-term and stable dynamic equilibrium exists in it.
\end{abstract}

Keywords—agricultural; economic; growth; relationship

\section{INTRODUCTION}

Since 2004, the CPC Central Committee, the State Council attached great importance to the "three rural" issue, "Food", agriculture is a major event livelihood, but also the people's survival plan. At present, agriculture is no longer just a productive sectors, it carries more social security, environmental protection and other functions. Agricultural production situation not only related to solve the "three rural" issue, but also a direct impact on achieving macroeconomic objectives of the intrinsic link mechanism of China's agricultural production and economic growth, empirical analysis has very important significance. Currently, agricultural production and promote economic growth theory to explain the main development economics agricultural surplus theory ${ }^{[1]}$. Comparative literature representative has Chen Xi, MengJie, according to 1952-2003 data on empirical analysis of long-term fluctuations of agricultural production and macroeconomic relations, the establishment of intersectoral equilibrium model to analyze the link agricultural production fluctuations and macroeconomic variables other sectors and contribution, studies have shown that fluctuations in agricultural production between macroeconomic volatility and strong interactions ${ }^{[3]}$.

\section{CURRENT SitUATION OF AGRICULTURE AND LOCAL ECONOMY IN MAOMING}

Maoming region economy maintained steady and rapid development in recent years, made a positive contribution for the promotion of the province regional harmonious development. In 2012, the city's GDP totaled 174.531 billion yuan, continue to maintain its leading position in the northwest region of Guangdong, is derived from the cities and counties in the fiscal and taxation total income of 32.716 billion yuan, in the north region forefront. GDP 5 years grew by an average of $11.4 \%$ a year, financial general budget revenue grew by an average of $20.8 \%$ a year for five years, were higher than the entire province average level. From the point of the data in table I to table $\Pi$, from 2007 to 2011, Maoming region GDP and per capita GDP growth trend year by year, smooth growth. Industrial production, animal husbandry, fishery output also showed a trend of growth, stable growth; Whole society fixed assets investment in addition to the declined in 2007, 2008 - 2011 are on the rise, and was bigger. Overall, 2001 - 2011 Maoming region of the national economy development situation is good, there is a growing tendency, better progressly. The data is showed in table 1 .

TABLE I. THE CITY'S GDP FROM 2007 TO 2011

\begin{tabular}{|c|c|c|c|c|c|c|c|c|}
\hline \multirow{2}{*}{ year } & $\begin{array}{l}\text { Gross } \\
\text { domestic } \\
\text { product }\end{array}$ & $\begin{array}{l}\text { The first } \\
\text { industry }\end{array}$ & $\begin{array}{c}\text { The } \\
\text { second } \\
\text { industry }\end{array}$ & $\begin{array}{c}\text { industri } \\
\text { al }\end{array}$ & $\begin{array}{c}\text { The } \\
\text { third } \\
\text { industry }\end{array}$ & \begin{tabular}{|c|} 
GDP \\
refers \\
to the \\
number
\end{tabular} & $\begin{array}{c}\text { The } \\
\text { first } \\
\text { industry }\end{array}$ & $\begin{array}{c}\text { The } \\
\text { second } \\
\text { industry }\end{array}$ \\
\hline & $\begin{array}{c}\text { (One } \\
\text { hundred } \\
\text { million } \\
\text { yuan) }\end{array}$ & $\begin{array}{c}\text { (One } \\
\text { hundred } \\
\text { million } \\
\text { yuan) }\end{array}$ & $\begin{array}{c}\text { (One } \\
\text { hundred } \\
\text { million } \\
\text { yuan) }\end{array}$ & $\begin{array}{c}\text { (One } \\
\text { hundred } \\
\text { million } \\
\text { yuan) }\end{array}$ & $\begin{array}{c}\text { (One } \\
\text { hundred } \\
\text { million } \\
\text { yuan) }\end{array}$ & $\mid \begin{array}{c}\text { Month- } \\
\text { on- } \\
\text { month } \\
\text { growth } \\
(\%)\end{array}$ & $\begin{array}{c}\text { Month- } \\
\text { on- } \\
\text { month } \\
\text { growth } \\
(\%)\end{array}$ & $\begin{array}{c}\text { Month- } \\
\text { on- } \\
\text { month } \\
\text { growth(\% } \\
)\end{array}$ \\
\hline 2007 & 997.08 & 198.89 & 403.29 & 367.89 & 394.9 & 13.1 & 4.5 & 16.6 \\
\hline 2008 & 1177.84 & 230.34 & 477.95 & 442.37 & 469.5 & 9.8 & 2.9 & 7.1 \\
\hline 2009 & 1231.25 & 240.44 & 460.79 & 426.79 & 530.0 & 10.3 & 5.3 & 5.2 \\
\hline 2010 & 1492.09 & 274.52 & 590.76 & 550.72 & 626.8 & 14.1 & 4.2 & 14.1 \\
\hline 2011 & 1745.31 & 319.27 & 696.66 & 645.80 & 729.3 & 10.8 & 4.2 & 13.4 \\
\hline
\end{tabular}




\section{MAOMING AGRICULTURE RELATIONSHIP WITH THE LOCAL ECONOMIC GROWTH}

Can be seen from the figure 1 in recent years in Maoming economy unceasing development, the growth of agricultural production in Maoming industry constantly, Maoming's gross domestic product (GDP) growth of 41.736 billion yuan to 41.736 billion yuan, Maoming amount of main agricultural products are grown from 114.5726 million tons to 114.5726 million tons. Almost in both increased year by year, and from the figure shows the two possible positive correlation. Output of major agricultural products ( $\mathrm{X}$ is Maoming, $\mathrm{Y}$ is Maoming gross domestic product (GDP)

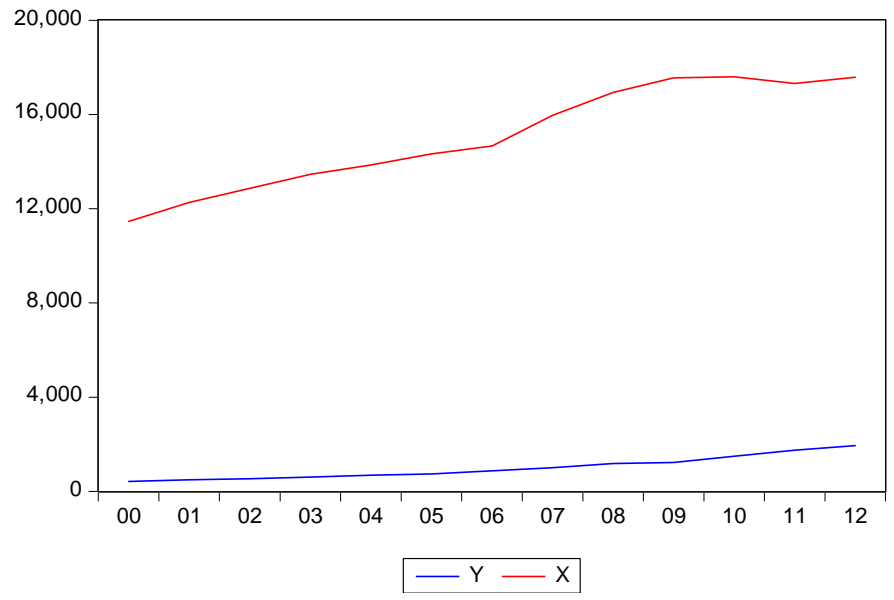

Fig. 1. Economic growth in Maoming

\section{DATA COLLECTION AND MODELING}

\section{A. Data Collection}

TABLE II. GRoss Domestic Product (GDP) IN THE City

\begin{tabular}{|c|c|c|c|c|c|c|}
\hline \multirow{3}{*}{ year } & \multirow{2}{*}{$\begin{array}{c}\text { Gross } \\
\text { domestic } \\
\text { product }\end{array}$} & \multicolumn{4}{|c|}{ GDP refers to the number } & \\
\hline & & $\begin{array}{l}\text { The first } \\
\text { industry }\end{array}$ & $\begin{array}{c}\text { The second } \\
\text { industry }\end{array}$ & industrial & $\begin{array}{l}\text { The third } \\
\text { industry }\end{array}$ & \\
\hline & $\begin{array}{c}\text { (One } \\
\text { hundred } \\
\text { million }\end{array}$ & $\begin{array}{l}\text { (One } \\
\text { hundred } \\
\text { million }\end{array}$ & $\begin{array}{l}\text { (One } \\
\text { hundred } \\
\text { million }\end{array}$ & $\begin{array}{c}\text { (One } \\
\text { hundred } \\
\text { million } \\
\end{array}$ & $\begin{array}{c}\text { (One } \\
\text { hundred } \\
\text { million }\end{array}$ & $\begin{array}{l}\text { Month-on- } \\
\text { month } \\
\text { growth }(\%)\end{array}$ \\
\hline 2000 & 417.36 & 125.91 & 147.72 & 122.78 & 143.73 & 11.2 \\
\hline 2001 & 485.34 & 126.46 & 202.16 & 178.61 & 156.72 & 10.3 \\
\hline 2002 & 537.72 & 139.25 & 221.04 & 193.49 & 177.44 & 10.2 \\
\hline 2003 & 610.78 & 155.81 & 253.09 & 220.87 & 201.89 & 11.3 \\
\hline 2004 & 685.16 & 174.33 & 264.69 & 227.01 & 246.15 & 14.2 \\
\hline 2005 & 738.35 & 167.04 & 259.49 & 229.02 & 311.83 & 14.1 \\
\hline 2006 & 872.95 & 180.25 & 348.82 & 312.11 & 343.88 & 13.9 \\
\hline 2007 & 997.08 & 198.89 & 403.29 & 367.89 & 394.90 & 13.1 \\
\hline 2008 & 1177.84 & 230.34 & 477.95 & 442.37 & 469.54 & 9.8 \\
\hline 2009 & 1231.25 & 240.44 & 460.79 & 426.79 & 530.02 & 10.3 \\
\hline 2010 & 1492.09 & 274.52 & 590.76 & 550.72 & 626.81 & 14.1 \\
\hline 2011 & 1745.31 & 319.27 & 696.66 & 645.80 & 729.38 & 10.8 \\
\hline 2012 & 1936.18 & 344.12 & 789.55 & 730.82 & 802.51 & 10.6 \\
\hline
\end{tabular}

TABLE III. GROSS DOMESTIC PRODUCT (GDP) IN THE CITY

\begin{tabular}{c|r|r|r|r}
\hline & $\begin{array}{c}\text { The first } \\
\text { industry }\end{array}$ & $\begin{array}{c}\text { The second } \\
\text { industry }\end{array}$ & industrial & The third industry \\
\cline { 2 - 5 } year & $\begin{array}{c}\text { Month-on- } \\
\text { month } \\
\text { growth(\%) }\end{array}$ & $\begin{array}{c}\text { Month-on- } \\
\text { month } \\
\text { growth(\%) }\end{array}$ & $\begin{array}{c}\text { Month-on- } \\
\text { month } \\
\text { growth(\%) }\end{array}$ & $\begin{array}{c}\text { Month-on- } \\
\text { month growth(\%) }\end{array}$ \\
\hline 2000 & 8.5 & 10.8 & 12.3 & 14.4 \\
2001 & 8.7 & 10.1 & 10.3 & 11.9 \\
2002 & 7.8 & 10.5 & 12.7 \\
2003 & 5.7 & 12.7 & 14.8 & 14.4 \\
2004 & 5.8 & 14.5 & 14.0 & 20.2 \\
2005 & 4.0 & 14.4 & 16.0 & 20.5 \\
2006 & 4.3 & 16.6 & 18.3 & 16.8 \\
2007 & 4.5 & 16.6 & 18.3 & 14.3 \\
2008 & 2.9 & 7.1 & 8.4 & 16.1 \\
2009 & 5.3 & 5.2 & 5.6 & 17.7 \\
2010 & 4.2 & 14.1 & 14.2 & 8.1 \\
2011 & 4.2 & 13.4 & 13.1 & 11.2 \\
2012 & 3.5 & 16.2 & 16.4 & \\
\hline
\end{tabular}

TABLE IV. MAIN Agriculture Product QuANTITY IN THE CITY

\begin{tabular}{|c|c|c|c|c|c|c|c|}
\hline \multirow{3}{*}{ year } & \multirow{2}{*}{$\begin{array}{l}\text { Pigs on } \\
\text { hand }\end{array}$} & \multirow{2}{*}{ Pigs are } & \multirow{2}{*}{$\begin{array}{l}\text { Poultry } \\
\text { market }\end{array}$} & \multirow{2}{*}{$\begin{array}{l}\text { Meatclass } \\
\text { The total } \\
\text { output of }\end{array}$} & \multicolumn{2}{|c|}{ Among them: } & \multirow{2}{*}{$\begin{array}{c}\text { Output } \\
\text { of } \\
\text { aquatic } \\
\text { products }\end{array}$} \\
\hline & & & & & pork & Poultry & \\
\hline & $\begin{array}{c}\text { (Ten } \\
\text { thousand) }\end{array}$ & $\begin{array}{c}\text { (Ten } \\
\text { thousand) }\end{array}$ & $\begin{array}{c}\text { (Ten } \\
\text { thousand) }\end{array}$ & $\begin{array}{c}\text { (Ten } \\
\text { thousand }\end{array}$ & $\begin{array}{c}\text { (Ten } \\
\text { thousand }\end{array}$ & $\begin{array}{c}\text { (Ten } \\
\text { thousand }\end{array}$ & $\begin{array}{c}\text { (Ten } \\
\text { thousand }\end{array}$ \\
\hline 2000 & 243.59 & 375.48 & 10701.48 & 42.52 & 29.40 & 12.46 & 52.33 \\
\hline 2001 & 248.26 & 399.50 & 11468.59 & 45.49 & 31.48 & 13.28 & 56.34 \\
\hline 2002 & 261.97 & 417.15 & 12037.36 & 47.62 & 32.83 & 13.94 & 57.85 \\
\hline 2003 & 280.31 & 442.99 & 12571.16 & 49.82 & 34.10 & 14.50 & 62.49 \\
\hline 2004 & 290.34 & 468.50 & 12928.48 & 52.46 & 35.93 & 15.20 & 64.49 \\
\hline 2005 & 294.67 & 499.01 & 13354.65 & 54.90 & 38.11 & 15.54 & 67.47 \\
\hline 2006 & 307.54 & 532.32 & 13639.78 & 56.31 & 39.34 & 15.95 & 70.33 \\
\hline 2007 & 323.38 & 505.89 & 14944.40 & 56.93 & 37.49 & 18.42 & 73.72 \\
\hline 2008 & 335.29 & 532.80 & 15875.54 & 60.27 & 39.78 & 19.52 & 74.67 \\
\hline 2009 & 337.09 & 550.52 & 16473.40 & 62.27 & 41.00 & 20.23 & 76.87 \\
\hline 2010 & 318.37 & 569.09 & 16506.31 & 64.02 & 42.64 & 20.31 & 79.24 \\
\hline 2011 & 323.66 & 559.75 & 16220.97 & 63.02 & 41.94 & 19.94 & 81.61 \\
\hline 2012 & 317.80 & 571.14 & 16478.65 & 64.38 & 42.73 & 20.43 & 84.06 \\
\hline
\end{tabular}

We can see the economic data in Maoming from table II to table III.

\section{B. Model Design}

With a gross domestic product (GDP) (y) of Maoming economic measure, on behalf of economic growth; Main agricultural output in Maoming $\left(\mathrm{X}_{1}\right)$ measure of agricultural growth. Using the data regression analysis.

Regression model is set as follows: 


$$
Y=\beta_{1}+\beta_{2} X_{1}+u
$$

$\mathrm{Y}$ represents gross domestic product (GDP) of Maoming, the $\mathrm{X}_{1}$ output of major agricultural products on behalf of Maoming, $u$ on behalf of the random perturbation terms. Based on the regression analysis of the model, it can be concluded that variable relationship with changes in China's economic growth.

\section{Estimation And Test Models}

\section{A. Model Estimation}

A preliminary estimate model:

TABLE V. The Preliminary Estimate Results

\section{Dependent Variable: $Y$}

Method: Least Squares

Date: 12/03/15 Time: 22:48

Sample: 20002012

Included observations: 13

\begin{tabular}{lclll}
\hline \hline \multicolumn{1}{c}{ Variable } & Coefficient & Std. Error & t-Statistic & Prob. \\
\hline \hline $\boldsymbol{C}$ & -2079.036 & 407.8741 & -5.097249 & 0.0003 \\
\multicolumn{1}{c}{$\boldsymbol{X}$} & 0.204023 & 0.026810 & 7.610009 & 0.0000 \\
\hline \hline & & & \\
R-squared & 0.840377 & Mean dependent var & 994.4162 \\
Adjusted R-squared & 0.825865 & S.D. dependent var & 492.6159 \\
S.E. of regression & 205.5658 & Akaike info criterion & 13.63005 \\
Sum squared resid & 464830.3 & Schwarz criterion & 13.71696 \\
Log likelihood & -86.59531 & Hannan-Quinn criter. & 13.61218 \\
F-statistic & 57.91224 & Durbin-Watson stat & 0.491236 \\
Prob(F-statistic) & 0.000010 & & \\
\hline \hline
\end{tabular}

According to the calculation result of table IV regression analysis, the regression equation is:

$$
\begin{aligned}
& Y=0.204023 X-2079.036 \\
& R^{2}=0.840377, F=57.91224
\end{aligned}
$$

After the adjustment $R^{2}=0.825865, D W=0.491236$

B. Text

\section{1) Significance Testing}

According to the above regression analysis, maoming agriculture and maoming local economic growth were positively correlated, and the practical significance.

2) Heteroscedasticity Inspection Graphical method:

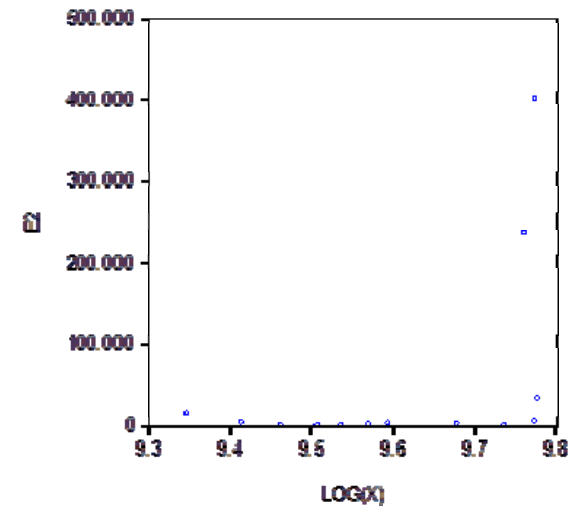

Fig. 2. Relationship between e2 with $\log (\mathrm{x})$

Can be seen from figure 2 residual squared E2 as explanatory variables $\log (\mathrm{X})$ the trend of the change is not obvious and there is no law, probably does not exist heteroscedastic model, but the existence of heteroscedasticity also should through the further inspection.

The ARCH inspection:

\section{TABLE VI. THE ARCH RESULTS}

\section{Dependent Variable: $Y$}

Method: ML - ARCH (Marquardt) - Normal distribution

Date: 12/04/15 Time: 15:25

Sample: 20002012

Included observations: 13

Failure to improve Likelihood after 25 iterations

\begin{tabular}{|c|c|c|c|c|}
\hline Variable & Coefficient & Std. Error & z-Statistic & Prob. \\
\hline$C$ & -1597.496 & 186.2093 & -8.579034 & 0.0000 \\
\hline $\boldsymbol{X}$ & 0.164995 & 0.011876 & 13.89258 & 0.0000 \\
\hline \multicolumn{5}{|c|}{ Variance Equation } \\
\hline$C$ & 23190.33 & 15900.26 & 1.458487 & 0.1447 \\
\hline $\operatorname{RESID}(-1)^{\wedge} 2$ & 3.881057 & 7.237019 & 0.536278 & 0.5918 \\
\hline GARCH(-1) & -1.063694 & 0.874238 & -1.216709 & 0.2237 \\
\hline$R$-squared & 0.759096 & \multicolumn{2}{|c|}{ Mean dependent var } & 994.4162 \\
\hline Adjusted R-squared & 0.737195 & \multicolumn{2}{|c|}{ S.D. dependent var } & 492.6159 \\
\hline S.E. of regression & 252.5370 & \multicolumn{2}{|c|}{ Akaike info criterion } & 12.93450 \\
\hline Sum squared resid & 701524.0 & \multicolumn{2}{|c|}{ Schwarz criterion } & 13.15179 \\
\hline Log likelihood & -79.07425 & \multirow{2}{*}{\multicolumn{2}{|c|}{ Hannan-Quinn criter. }} & 12.88984 \\
\hline Durbin-Watson stat & 0.287493 & & & \\
\hline
\end{tabular}

Presample variance: backcast (parameter $=0.7$ )

$G A R C H=C(3)+C(4) * R E S I D(-1)^{\wedge} 2+C(5) * G A R C H(-1)$ 
From the table $\mathrm{V}$ can get the data:

$(n-p) R^{2}=9.868246$ Look-up table to

$\chi^{2}(p)=12.88984,(n-p) R^{2}=9.868248<\chi^{2}(p)=12.88984$

Received the original assumption, there is no

heteroscedasticity.

\section{Autocorrelation Correction}

Graphic method:

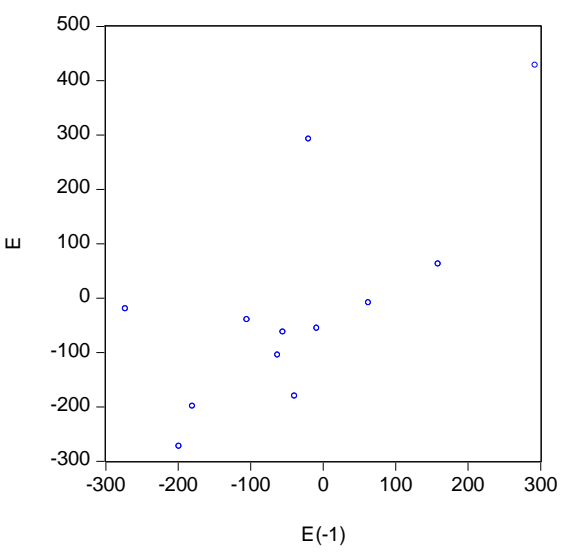

Fig. 3. Relationship between e with e(-1)

As can be seen from the figure 3 obvious residual et, show that $\mathrm{U}^{\mathrm{T}}$ haven't related to the random error.

The final regression model: $\quad Y=0.204023 X-2079.036$

$$
R^{2}=0.759096, F=57.91224, D W=0.287493
$$

Shows that in the case of other conditions unchanged, Maoming main agricultural production increase of 14.5023 million tons, Maoming local GDP increase of 100 million yuan.

\section{CONCLUSION ANALYSIS AND PoliCy RECOMMENDATIONS}

\section{A. Conclusion Analysis}

1. Maoming agriculture positively correlated with the local economic growth, the development of Maoming agriculture has promoted to the local economic growth, agricultural production and economic growth between the long-term stability of the dynamic equilibrium relationship. Pull function on the economic growth of agricultural production is quite large, agricultural output value of every increase of 14.5023 million tons, will promote the economic growth of 100 million yuan.

2. In the end use econometric method to eliminate the heteroscedastic model, finally get the statistical test, and high goodness of fit of the model.

3. Error correction model, the results showed that the short-term changes of agricultural production has significant positive effect on economic growth, economic growth after the interference to faster adjustment to its long-term growth path.

\section{B. Policy Suggestion}

The government should be more perfect and more benefit farming policy, attaches great importance to the development of agriculture, increasing farmers' income, improve the living standards of farmers, narrow the gap between rich and poor. The development of agriculture is the foundation of country, agriculture is the country's future and the development, as Maoming, has a unique natural resource conditions, more should vigorously develop agriculture, to better support the development of other industries, continuously improve the economic level of Maoming.

\section{ACKNOWLEDGMENT}

It is a pleasure to acknowledge the support of the project from XU Yan-li being selected in the introduction of shortage top talent of "Sailing up (Yangfan) project" in Guangdong Province in 2014. The project is Leading Industry Development Strategy Research in Emerging Areas in Western Guangdong for Accelerating the Economic Development of Western Guangdong.

It is a pleasure to acknowledge the support from the talents introduction project of universities in Guangdong Province. The project is the Coordinating Development Model Construction and the Path Research of Technical Capability and Technology Management Capability in Equipment Manufacturing Industry.

It is also a pleasure to acknowledge the support from Research Base of Practicing the Scientific Development Outlook of Guangdong Province (2014JD08, 2014JD09), Research Base for the Coordinated Development of Urban and Rural Areas, Outstanding New Majors Project (11428), Collaborative Innovation Center for Silk Road in Southern China Sea, Regional Development Research Institute in Western Guangdong, etc, in Lingnan Normal University.

\section{REFERENCES}

[1] Zhao junping. Main Power Consumption Economic Growth of China [J], 2005

[2] $\mathrm{Xu}$ Zheng, Run-qing Zhang. China's Economic Growth Factors Empirical Analysis [J], Economic BBS, 2007 (04)

[3] Qi Guoping. China's Economic Growth: An Empirical Study of Factors Affecting Anhui Finance and Economics

[4] Wu pei, Li kejun. An Empirical Analysis of the Factors that Affect China's Economic Growth. Xihua University, Chengdu

[5] Liu shibai. And the Socialist Market Economy Theory. Southwestern University of Finance and Economics Press

[6] Ceinet Statistics Database

[7] Maoming Statistics Network

[8] Deng haiguang. Maoming New Breakthroughs were Made in the New Economic and Social Development Achievements.

[9] Zhao junping, Jiang zhuwei, feng-sheng Li. Macroeconomics Tutorial [M]. Harbin: Northeast Forestry University Press, 2007:270-271.

[10] Mr Chirac, Ling-jiemeng. Agricultural Production and the Empirical Analysis and Prediction of Macroeconomic Fluctuation Relationship for a Long Time 